\title{
THE PHARMACOEPIDEMIOLOGICAL ANALYSIS OF THE CONSUMPTION OF ANTIMICROBIAL DRUGS FOR SYSTEMIC USE IN OUTPATIENT PRACTICE
}

The study of the consumption of antimicrobial drugs (AMD) is an important component of comprehensive programs for infection control and antibiotic resistance prevention. The information on the consumption of AMD reflects the implementation of standards of medical care, as well as the opinion of the population and pharmaceutical professionals on the problems of prevention and treatment of infectious diseases.

Aim. To assess the regional consumption market of AMD for systemic use in the outpatient practice of the Republic of Tajikistan.

Materials and methods. The ATC classification recommended by the WHO and the Defined Daily doses system were used to quantify the AMD consumption. The number of DDDs of AMD used was expressed as the number of DDD per 1.000 inhabitants a day (DID).

Results. The study of the retail segment of the market for antibacterial drugs revealed an increase in the consumption of the most significant groups of AMD: $\beta$-lactam antibiotics and fluoroquinolones both quantitatively and in monetary terms. Among medicines by international non-proprietary names ciprofloxacin is the most consumed drug in all periods studied. There is an increase in the consumption of tetracycline hydrochloride, azithromycin, ofloxacin, erythromycin. The consumption of chloramphenicol, pipemidic acid and pefloxacin decreased.

Conclusions. The analysis of the retail segment of the market of antibacterial drugs in Dushanbe in 2014-2016 has revealed an increase in the consumption of $\beta$-lactam antibiotics and fluoroquinolones. In the retail turnover of the region AMD, which are not recommended for widespread use in outpatient settings, are also widely represented.

Key words: pharmacoepidemiological analysis; antibacterial drugs; outpatient practice.

\section{Л. В. САВЧЕНКОВА, М. Н. САЇДОВА, Д. К. ХОМІДОВ}

ФАРМАКОЕПІДЕМІОЛОГІЧНИЙ АНАЛІЗ ВИКОРИСТАННЯ АНТИМІКРОБНИХ ЛІКАРСЬКИХ ЗАСОБІВ ДЛЯ СИСТЕМНОГО ЗАСТОСУВАННЯ В АМБУЛАТОРНІЙ ПРАКТИЦІ

Дослідження споживання антимікробних лікарських засобів (ЛЗ) є важливим компонентом комплексних програм з контролю за інфекціями і профілактики антибіотикорезистентності. Відомості про споживання антимікробних ЛЗ відображають виконання стандартів медичної допомоги, $\epsilon$ відбитком думки населення і фармацевтичних працівників щодо проблем профілактики і лікування інфекційних захворювань.

Мета: оцінка регіонального ринку споживання антимікробних ЛЗ для системного застосування в амбулаторній практиці Республіки Таджикистан.

Матеріали та методи. Для кількісного опису споживання антимікробних ЛЗ використовувалася рекомендована В003 АТС класифікація і система «умовних добових доз» (Defined Daily Doses (DDD). Кількість DDD використаних антимікробних ЛЗ виражалася у вигляді кількості DDD на 1000 жителів на день (DID).

Результати дослідження. Дослідження роздрібного сегмента ринку антибактеріальних ЛЗ виявило зростання споживання за обсягами, як у кількісному, так і грошовому вираженні, $\beta$-лактамних антибіотиків та фторхінолонів. Серед лікарських засобів за міжнародною непатентованою назвою в усі досліджувані строки найбільш споживаним ЛЗ $є$ ципрофлоксацин. Відмічається збільшення споживання тетрацикліну гідрохлориду, азитроміцину, офлоксацину, еритроміцину. Знизилось споживання хлорамфеніколу, піпемідинової кислоти та пефлоксацину.

Висновки. Аналіз роздрібного сегмента ринку антибактеріальних ЛЗ у м. Душанбе в 2014-2016 pp. виявив зростання споживання $\beta$-лактамних антибіотиків та фторхінолонів. У роздрібному товарообігу регіону також широко представлено антимікробні ЛЗ, що не рекомендовані для широкого застосування в амбулаторно-поліклінічних умовах.

Ключові слова: фармакоепідеміологічний аналіз; антибактеріальні лікарські засоби; амбулаторна практика. 


\section{Л. В. САВЧЕНКОВА, М. Н. САИДОВА, Д. К. ХОМИДОВ}

\section{ФАРМАКОЭПИДЕМИОЛОГИЧЕСКИЙ АНАЛИЗ ИСПОЛЬЗОВАНИЯ АНТИМИКРОБНЫХ ЛЕКАРСТВЕННЫХ СРЕДСТВ ДЛЯ СИСТЕМНОГО ПРИМЕНЕНИЯ В АМБУЛАТОРНОЙ ПРАКТИКЕ}

Исследование потребления антимикробных препаратов (АМП) является важным компонентом комплексных программ по контролю за инфекциями и профилактике антибиотикорезистентности. Сведения о потреблении АМП отражают выполнение стандартов медицинской помощи, являются отражением мнения населения и фармацевтических работников о проблемах профилактики и лечения инфекционных заболеваний.

Цель: оценка регионального рынка потребления АМП для системного применения в амбулаторной практике Республики Таджикистан.

Материалы и методы. Для количественного описания потребления АМП использовалась рекомендованная В03 ATC-классификация и система «условных суточных доз» (Defined Daily Doses (DDD). Количество DDD использованных AMП выражалось в виде количества DDD на 1000 жителей в день (DID).

Результаты исследования. Исследование розничного сегмента рынка антибактериальных препаратов выявило рост потребления, как в количественном, так и денежном выражении, наиболее значимых групп АМП: $\beta$-лактамных антибиотиков и фторхинолонов. Среди лекарственных средств по международным непатентованным названиям во все исследуемые сроки наиболее потребляемым препаратом является ципрофлоксацин. Отмечается увеличение потребления тетрациклина гидрохлорида, азитромицина, офлоксацина, эритромицина. Снизилось потребление хлорамфеникола, пипемидовой кислоты и пефлоксацина.

Выводы. Анализ розничного сегмента рынка антибактериальных препаратов в г. Душанбе в 2014-2016 гг. выявил рост потребления $\beta$-лактамных антибиотиков и фторхинолонов. В розничном товарообороте региона также широко представлены АМП, которые не рекомендованы для широкого применения в амбулаторно-поликлинических условиях.

Ключевые слова: фармакоэпидемиологический анализ; антибактериальные лекарственные средства; амбулаторная практика.

Antimicrobial drugs (AMD) are one of the classes of drugs that are prescribed in clinical practice most often, and constitute a significant part of financial expenses. It is necessary to emphasize that prescription of AMD for the treatment of infectious diseases is irrational in large part from the point of view of indications for use, dose regimen, etc. However, the real scale of the problem has not yet been determined since many AMD owing to the peculiarities of the state regulation of this sector of the regional pharmaceutical market are sold in the form of OTC drugs [1]. This gives the possibility of the AMD consumption in various variants: self-treatment, their recommendation by pharmacists who, as a rule, do not have information about the patient's health, within the "network marketing" technology and other forms [2]. At the same time, the use of AMD is significantly correlated with the level of antibiotic resistance. Resistant microorganisms lead to a prolonged course of disease, frequent and longer hospitalization and higher mortality, as well as additional costs when providing medical care not only for a patient who takes the specific AMD, but also for those who are only potential users of this class of drugs [3].

Sales of AMD by pharmacies fully reflects the availability of medical care for the general population, the supply of drugs to hospitals shows the doctor's competence in prescribing this class of drugs, as well as public the opinion of AMD in the self-treatment. In this regard, the study of the consumption of AMD in a particular area is an important component of comprehensive programs for infection control and antibiotic resistance prevention.

The aim of the study was to assess the consumption of AMD for systemic use in the outpatient practice according to their sales at the regional market of the Republic of Tajikistan.

Materials and methods. As a source of information on the use of AMD for systemic use the data of sales in pharmacies working in Dushanbe, Tajikistan (the wholesale pharmaceutical networks "Dusti" and "Dar Dar") were taken for the period of 2014-2016. For the quantitative description of the AMD consumption the ATC classification recommended by the WHO and the Defined Daily doses system (DDD) were used [4]. The number of DDDs of AMD used was expressed as the number of DDD per 1,000 inhabitants a day (DID), and the AMD consumption in the number of packs sold was also studied. The DDD value for each drug was taken from the Information Center of the drug consumption of the WHO [5]. The information on the population was obtained from the publications of the State Statistics Committee of 


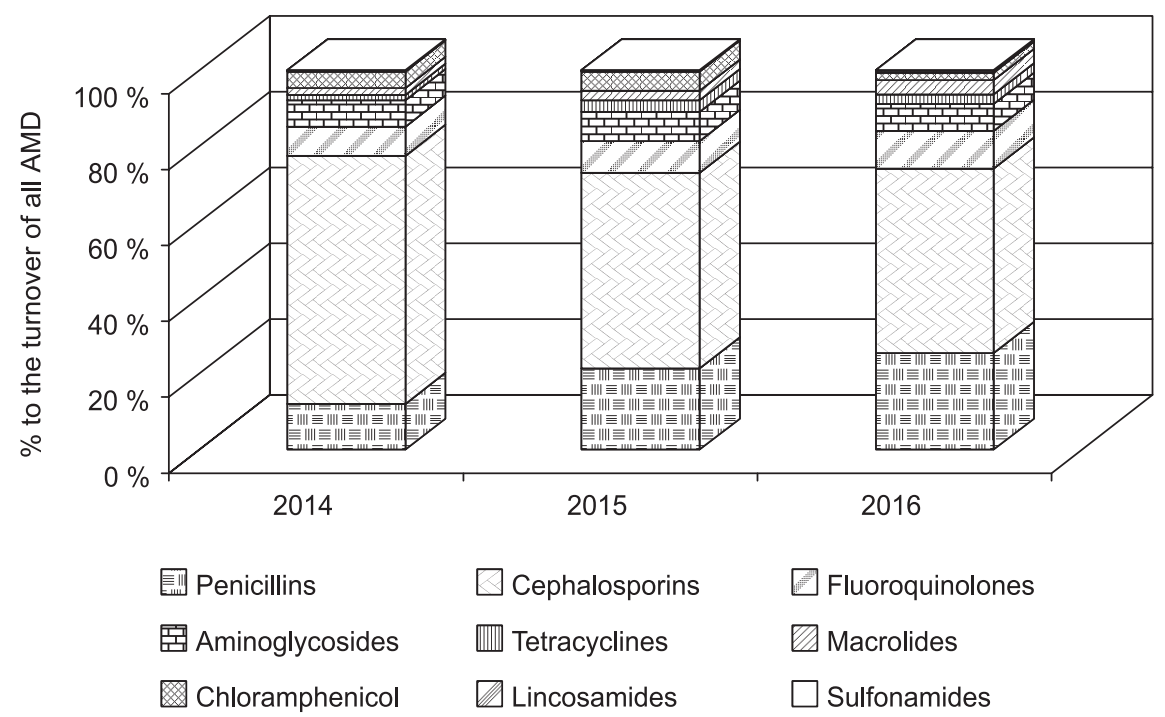

Fig. 1. The sales volume of major groups of antibacterial drugs in value terms in 2014-2016

the Republic of Tajikistan. The statistical processing of the results was performed by the methods of descriptive statistics using MS Office Excel 2000 software.

Results and discussion. The overall analysis of retail sales in Dushanbe showed that sales of AMD for systemic use compared to the total sales of all drugs in monetary terms for the period from 2014 to 2016 increased significantly from 2.4 to $5.7 \%(\mathrm{p}<0.05)$, respectively. The highest indicators of financial costs within 2014-2016 fall to the group of $\beta$-lactam antibiotics (approximately 73-77 \% in different years of observation). At the same time, among $\beta$-lactam antibiotics cephalosporins are definitely leading (48-65 \% in different years of observation). The share of expenditure on macrolides and fluoroquinolones are comparable in all years studied (Fig. 1).

In the structure of sales in monetary terms by the international non-proprietary names (INN) up to $80 \%$ of the market falls on the first 5 AMD in the rating, moreover, ceftriaxone is more than $40 \%$.

The second highest cost is ampicillin with the percentage of costs ranging from $5.5 \%$ to $14 \%$ during these years. The costs for ciprofloxacin, amoxicillin, cefazolin are within $5 \%-8 \%$.

The dynamics from 2014 to 2016 there was a significant increase in the consumption of ampicillin and amoxicillin in monetary terms by almost 2.5 and 2.0 times - from 5.5 to $14.2 \%$ and from 3.89 to $8.15 \%$, respectively. Despite the fact that the absolute leader in terms of sales is ceftriaxion, the costs of the consumption of this drug in the dynamics for three years have a stable tendency to decrease, which may be due to the use of cheaper drugs. Moreover, it is possible to determine the cause of this dynamic only while analyzing and comparing costs and volumes of the consumption of this drug. In parallel, there was a decrease in the consumption of chloramphenicol, pipemidic acid and josamycin in monetary terms. The other drugs had a tendency (although insignificant) to increase the consumption (Tab. 1).

When analyzing the consumption of AMD for systemic use through the pharmacy network the annual increase in the AMD consumption from 8.43 DID in 2014 to 16.3 DID in 2016 $(\mathrm{p}<0.05)$ attracts attention (Fig. 2).

The greatest proportion of the consumption by the population among AMD is in antibacterial drugs from the group of penicillins and fluoroquinolones. The consumption of penicillins has grown almost 3.1 times for 3 years, and drugs from this group for the past two years are the leaders by their consumption.

In many respects this is explained, on the one hand, by affordability of this group of drugs, and on the other hand, by a wide range of activities and a sufficiently high level of safety of the latter. The third place in the rating during all the years of our study is occupied by the group of cephalosporin antibiotics, and it can not be considered substantiated taking into account the fact that drugs of this group are drugs of a wide spectrum of action and 
Table 1 are mainly used parenterally at the inpatient

THE SALES VOLUME OF THE MAIN AMD IN VALUE TERMS IN 2014-2016

\begin{tabular}{|l|c|c|c|}
\hline \multirow{2}{*}{ The name of AMD } & \multicolumn{3}{|c|}{ \% to the turnover } \\
\cline { 2 - 4 } & 2014 & 2015 & 2016 \\
\hline Ceftriaxone & 62.217 & 42.509 & 40.693 \\
\hline Ampicillin & 5.537 & 10.418 & 14.163 \\
\hline Ciprofloxacin & 5.637 & 7.501 & 8.342 \\
\hline Amoxicillin & 3.898 & 8.137 & 8.147 \\
\hline Cefazolin & 3.165 & 8.692 & 7.459 \\
\hline Amikacin sulfate & 6.065 & 5.796 & 5.107 \\
\hline Benzylpenicillin sodium & 2.152 & 2.290 & 2.502 \\
\hline Tetracycline & 1.240 & 2.798 & 2.217 \\
\hline Erythromycin & 0.594 & 1.634 & 2.115 \\
\hline Levomycetin & 4.246 & 4.976 & 1.958 \\
\hline Gentamicin sulphate & 0.782 & 1.746 & 1.832 \\
\hline Azithromycin & 0.563 & 0.711 & 1.362 \\
\hline Ofloxacin & 0.446 & 0.313 & 0.935 \\
\hline Lincomycin & 0.377 & 0.331 & 0.605 \\
\hline Bicillin-3 & 0.278 & 0.395 & 0.429 \\
\hline Pefloxacin & 0.927 & 0.460 & 0.409 \\
\hline Ceftazidime & - & 0.276 & 0.396 \\
\hline Oletetrine & 0.188 & 0.293 & 0.259 \\
\hline Bicillin -5 & 0.261 & 0.151 & 0.224 \\
\hline Pipemidinic acid & 0.639 & 0.166 & 0.221 \\
\hline Josamycin & 0.623 & 0.161 & 0.211 \\
\hline Kanamycin & 0.121 & 0.095 & 0.198 \\
\hline Spiramycin & 0.040 & 0.046 & 0.097 \\
\hline Cefotaxime & - & 0.095 & 0.094 \\
\hline & & & \\
\hline
\end{tabular}

Note: cefepime, cephalexin, sulfadimezin, sulfadimethoxin, streptomycin are less than $0.01 \%$ of sales stage of treatment. This may be due to the increase of self-treatment practice with antibacterial drugs, which leads to an aggravation of the course of diseases and formation of a high level of complications; it substantiates prescription of cephalosporins with a wide spectrum of action.

In the fourth place during 2015-2016 there is the group of tetracycline antibiotics, their share of the consumption has doubled in the last 3 years, which is probably due to the broad inclusion of this group of drugs in the treatment of diseases of the gastrointestinal tract of Helicobacter pylori and the use of these drugs in veterinary medicine. It should be noted that there is a stable tendency to increase (more than 5.1 times) of the consumption of macrolide antibiotics. This fact is primarily explained by the high antibacterial activity, a broad spectrum of the antibacterial action, the ability to affect the non-bacterial flora (chlamydia, toxoplasma), improved pharmacokinetic characteristics and an acceptable safety profile.

Despite the fact that the absolute leaders in terms of consumption as a whole are drugs from the penicillin group, among the individual drugs by INN for all periods studied the antimicrobial drug from the group of fluoroquinolones - ciprofloxacin is the most consumed, its DID / 1000 inhabitants / day is the largest and fluctuates in the range of 3.0-4.7 DID (Tab. 2). It should be also noted that the consumption of this drug from 2014 to 2016 almost
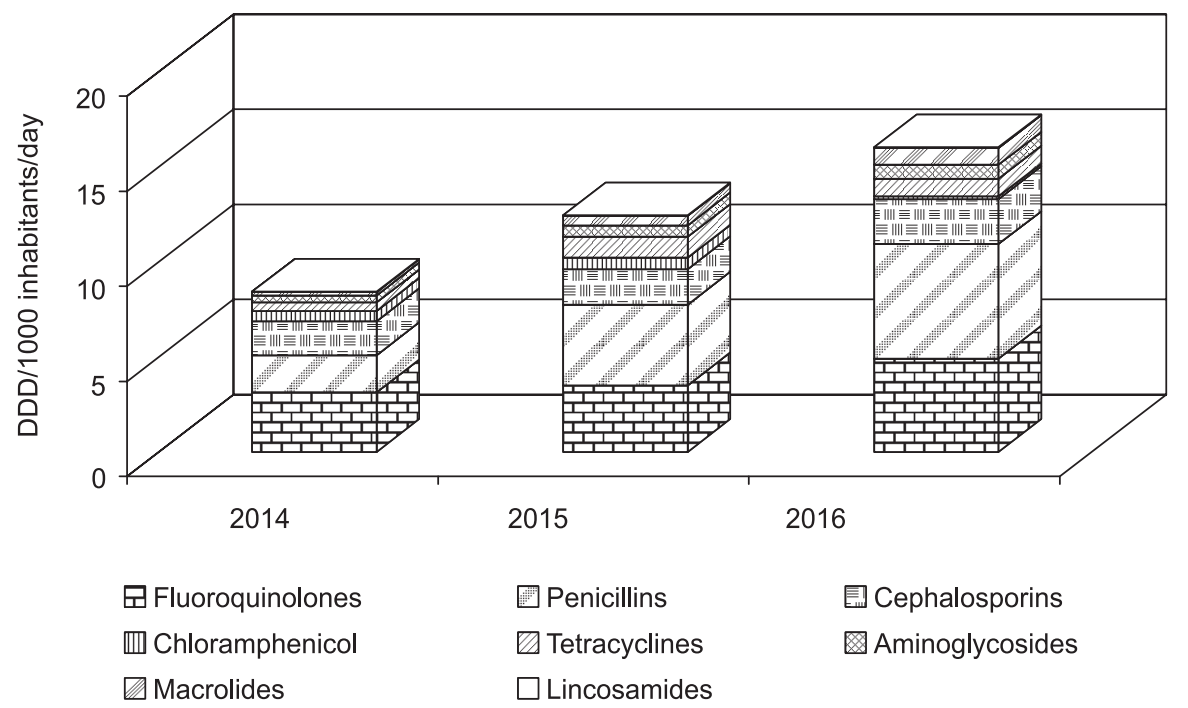

Fig. 2. The comparative structure of the consumption of the main groups of antibacterial drugs in 2014-2016 


\section{THE COMPARATIVE STRUCTURE OF THE AMD CONSUMPTION IN 2014-2016 BY INN (DDD/1000 INHABITANTS/DAY)}

\begin{tabular}{|l|c|c|c|c|c|c|}
\hline \multirow{2}{*}{ The name of AMD } & \multicolumn{7}{|c|}{ DDD/1000 inhabitants/day } \\
\cline { 2 - 7 } & 2014 & $\begin{array}{c}\text { The place in } \\
\text { the rating }\end{array}$ & 2015 & $\begin{array}{c}\text { The place in } \\
\text { the rating }\end{array}$ & 2016 & $\begin{array}{c}\text { The place in } \\
\text { the rating }\end{array}$ \\
\hline Ciprofloxacin & 2.992 & 1 & 3.408 & 1 & 4.697 & 1 \\
\hline Ceftriaxone & 1.662 & 2 & 1.454 & 3 & 1.937 & 3 \\
\hline Amoxicillin & 0.921 & 3 & 2.622 & 2 & 3.357 & 2 \\
\hline Chloramphenicol & 0.533 & 4 & 0.595 & 6 & 0.130 & 13 \\
\hline Tetracycline & 0.449 & 5 & 1.074 & 4 & 0.923 & 5 \\
\hline Ampicillin & 0.445 & 6 & 0.992 & 5 & 1.848 & 4 \\
\hline Benzylpenicillin sodium salt & 0.332 & 7 & 0.333 & 10 & 0.459 & 8 \\
\hline Gentamycin sulfate & 0.253 & 8 & 0.476 & 7 & 0.553 & 7 \\
\hline Bicillin-3 & 0.191 & 9 & 0.257 & 11 & 0.316 & 10 \\
\hline Cefazolin & 0.130 & 10 & 0.414 & 8 & 0.423 & 9 \\
\hline Erythromycin & 0.119 & 11 & 0.387 & 9 & 0.596 & 6 \\
\hline Amikacin sulfate & 0.081 & 12 & 0.102 & 13 & 0.118 & 14 \\
\hline Bicillin-5 5 & 0.065 & 13 & 0.034 & 15 & 0.058 & 15 \\
\hline Pefloxacin & 0.058 & 14 & 0.028 & 16 & 0.027 & 18 \\
\hline Piperidic acid & 0.053 & 15 & 0.013 & 20 & 0.017 & 19 \\
\hline Azithromycin & 0.050 & 16 & 0.119 & 12 & 0.291 & 11 \\
\hline Ofloxacin & 0.031 & 17 & 0.058 & 14 & 0.171 & 12 \\
\hline Kanamycin & 0.028 & 18 & 0.024 & 17 & 0.055 & 16 \\
\hline Lincomycin & 0.019 & 19 & 0.024 & 18 & 0.039 & 17 \\
\hline
\end{tabular}

Note: the consumption is less than 0.01 DID / 1000 inhabitants / day: sulfadimethoxin, sulfadimezin, spiramycin, cefepime, ceftazidime, cefotaxime, cephalexin, streptomycin, josamycin, oletetrin.

doubled. The consumption of ampicillin for the period studied increased almost 4 times, amoxicillin - 3.6 times. The specific weight of ceftriaxone consumption increased only by $17 \%$ for the period under study.

It should be separately noted that intake of tetracycline hydrochloride almost twice increased within the years under study. In addition, it is important that there is the increase in demand for some groups of AMD although they have a low level of consumption by DID/1000 inhabitants/day, e.g. for azithromycin in 5.8 times, ofloxacin - 5.5 times, erythromycin - 5 times, gentamicin, kanamycin and bicillin-3 - almost 2 times and amikacin sulfate and benzylpenicillin sodium salt -1.5 times.

At the same time, the consumption of chloramphenicol, which ranked the 4-th place in 2014, decreased by 4 times, and in 2016 by DID/1000 inhabitants/day the drug was the 13th. The consumption of pipemidic acid decreased almost by 3 times, and pefloxacin decreased twice.
To understand the causes of dynamics of the AMD consumption given above the role and influence of drug prices on their demand and consumption in the retail segment of the drug market was further analyzed. As one can see from Fig. 3, there is a fairly significant increase in the average weighted price for ceftriaxone for three years analyzed, and an insignificant, but gradual increase in the cost of ciprofloxacin, while the weighted average price for amoxicillin remains at the same level.

The data obtained allow making a conclusion that the weighted average price of the most commonly used antimicrobial drugs has no significant impact on the volume of their sales.

When analyzing the consumption of AMD in the context of retail sales, the attention is drawn to the fact that in addition to drugs recommended for use in outpatient practice in the known protocols (standards) of medical care a significant number of antibacterial drugs with a high level of resistance to microorganisms 


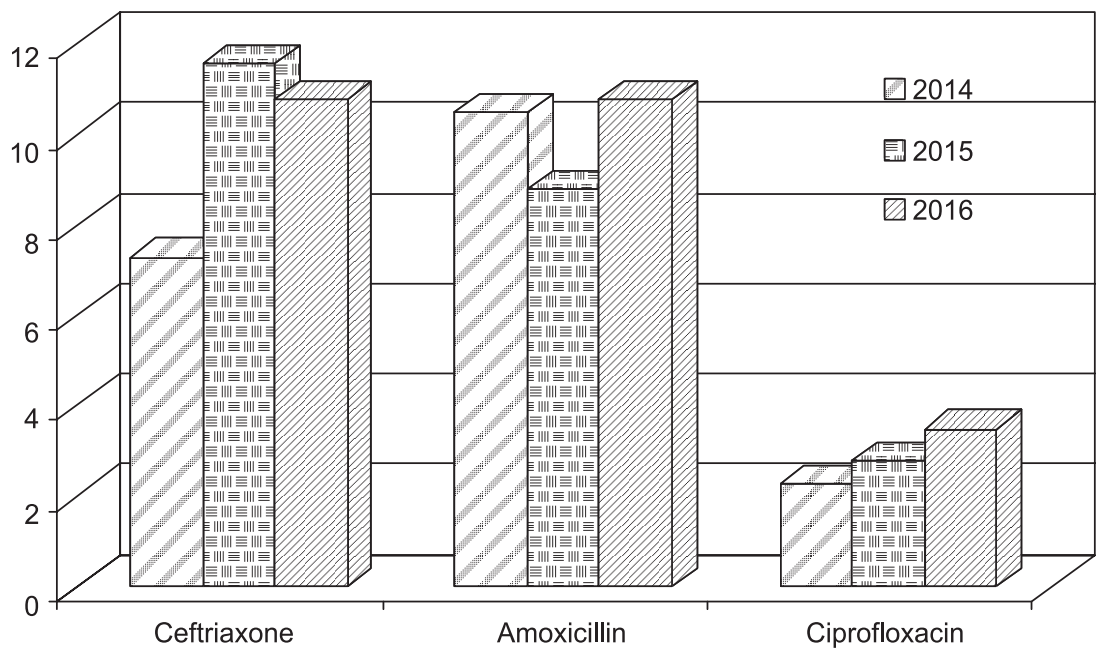

Fig. 3. Dynamics of the weighted average price for the most commonly used AMD in 2014-2016

are present in the regional retail turnover and are recommended for consumption. These are such drugs as sulfadimethoxin, sulfadimezin, chloramphenicol, etc. The insignificant, but apparent increase in the consumption of drugs, which have a wide range of restrictions to their routine use in outpatient practice, are of a special alarm. For example, in retail sales there are drugs used in a limited way, such as streptomycin, for the treatment of patients with tuberculosis infection, as well as antibacterial medicines for the treatment of severe infectious diseases, such as gentamycin sulfate, amikacin, cefepime, ceftazidime, cefoperazone, kanamycin.

Conclusions. The analysis of the retail segment of the market of antibacterial drugs in Dushanbe in 2014-2016 has revealed an increase in the consumption of $\beta$-lactam antibiotics and fluoroquinolones. In the retail turnover of the region antimicrobial drugs, which are not recommended for widespread use in outpatient settings, are widely represented.
According to the existing protocols for provision of medical care they are drugs that are intended for use in hospital settings. The latter fact can be explained from the point of view of expanding the practice of self-treatment of various groups of diseases by the majority of age groups of the population due to the considerable distance to the primary care facilities or the shortage of doctors. The increase of the practice of self-treatment with antibacterial drugs leads to aggravation of the course of diseases and formation of a high level of complications, and it substantiates prescription of antibacterial drugs with a wide spectrum of action. It is impossible to exclude a significant increase of aggression in the structure of the marketing policy of regional pharmaceutical companies.

The data obtained is the basis for determining the strategy for the effective use of AMD in regional conditions.

Conflicts of Interests: authors have no conflict of interests to declare.

\section{References}

1. Влияние фармацевтов на практику самолечения респираторных инфекций / С. Н. Козлов, С. А. Рачина, Л. С. Страчунский и др. // Ремедиум. - 2005. - № 11. - С. 45-49.

2. Лещенко, И. В. Внебольничная пневмония: от национальных рекомендаций к региональным стандартам / И. В. Лещенко, З. Д. Бобылева, Н. М. Трифанова // Клиническая медицина. - 2014. - № 6. - C. 35-40.

3. ESAC Project Group. Outpatient antibiotic use in Europe and association with resistances cross-national database study / H. Goossens, M. Ferech, M. Elseviers et al. // Lancet. - 2005. - Vol. 365, № 10. - P. 579-587. doi : 10.1016/s0140-6736(05)70799-6.

4. DANMAP 2011. Use of antimicrobial agents and occurrence of antimicrobial resistance in bacteria from food animals, food and humans in Denmark. - Retrieved from: http://www.danmap.org (дата обращения 22.01.2013).

5. About ATC/DDD system. - Oslo : World Health Organization Collaborating Center for Drug Statistics Methodology. - Retrieved from: http://www. whocc.no/ATC/DDD (дата обращения 22.01.2013). 


\section{References}

1. Kozlov, S. N., Rachina, S. A., Strachunskii, L. S. (2005). Remedium, 11, 45-49.

2. Leshchenko, I. V., Bobyleva, Z. D., Trifanova, N. M. (2014). Klinicheskaia meditsyna, 6, 35-40.

3. Goossens, H., Ferech, M., Elseviers, M. et al. (2005). ESAC Project Group. Outpatient antibiotic use in Europe and association with resistances cross-national database study. Lancet, 365 (10), 579-587. doi: 10.1016/s0140-6736(05)70799-6.

4. DANMAP. (2011). Use of antimicrobial agents and occurrence of antimicrobial resistance in bacteria from food animals, food and humans in Denmark. Retrieved from: http://www.danmap.org.

5. About ATC/DDD system. Oslo: World Health Organization Collaborating Center for Drug Statistics Methodology. Retrieved from: http://www.whocc.no/ATCDDD.

Information about authors:

Savchenkova L. V., Doctor of Medicine (Dr. habil.), professor, head of the Department of Pharmacy, Tajik National University. E-mail: slv.05@mail.ru

Saidova M. N., Candidate of Pharmacy (Ph.D.), associate professor of the Department of Pharmacy, Tajik National University.

E-mail: narzullos@mail.ru

Khomidov D. K., teaching assistant of the Department of Pharmacy, Tajik National University. E-mail: daler-khamidov@mail.ru Відомості про авторів:

Савченкова Л. В., доктор медичних наук, професор, завідувач кафедри фармації, Таджицький національний університет. E-mail: slv.05@mail.ru

Caїдова M. H., кандидат фармацевтичних наук, доцент кафедри фармації, Таджицький національний університет. Е-таіl: narzullos@mail.ru

Хомідов Д. К., асистент кафедри фармації, Таджицький національний університет. E-mail: daler-khamidov@mail.ru Сведения об авторах:

Савченкова Л. В., доктор медицинских наук, профессор, заведующая кафедрой фармации, Таджикский национальный университет. E-mail: slv.05@mail.ru

Caидова M. H., кандидат фармацевтических наук, доцент кафедры фармации, Таджикский национальный университет E-mail: narzullos@mail.ru

Хомидов Д. К., ассистент кафедры фармации, Таджикский национальный университет. E-mail: daler-khamidov@mail.ru 